\title{
Gevolgen van het Nederlanderschap : gezondheid, recht en economie
}

Citation for published version (APA):

Hofstede, G. H. (1987). Gevolgen van het Nederlanderschap : gezondheid, recht en economie.

Rijksuniversiteit Limburg. https://doi.org/10.26481/spe.19870515gh

Document status and date:

Published: 15/05/1987

DOI:

10.26481/spe.19870515gh

Document Version:

Publisher's PDF, also known as Version of record

\section{Please check the document version of this publication:}

- A submitted manuscript is the version of the article upon submission and before peer-review. There can be important differences between the submitted version and the official published version of record.

People interested in the research are advised to contact the author for the final version of the publication, or visit the DOI to the publisher's website.

- The final author version and the galley proof are versions of the publication after peer review.

- The final published version features the final layout of the paper including the volume, issue and page numbers.

Link to publication

\footnotetext{
General rights rights.

- You may freely distribute the URL identifying the publication in the public portal. please follow below link for the End User Agreement:

www.umlib.nl/taverne-license

Take down policy

If you believe that this document breaches copyright please contact us at:

repository@maastrichtuniversity.nl

providing details and we will investigate your claim.
}

Copyright and moral rights for the publications made accessible in the public portal are retained by the authors and/or other copyright owners and it is a condition of accessing publications that users recognise and abide by the legal requirements associated with these

- Users may download and print one copy of any publication from the public portal for the purpose of private study or research.

- You may not further distribute the material or use it for any profit-making activity or commercial gain

If the publication is distributed under the terms of Article $25 \mathrm{fa}$ of the Dutch Copyright Act, indicated by the "Taverne" license above, 


\section{GEVOLGEN VAN HET NEDERLANDERSCHAP}

GEZONDHEID, RECHT EN ECONOMIE

Rede

Uitgesproken bij de aanvaarding van

het Hoogleraarschap in

de Vergelijkende Cultuurstudies van Organisaties

en van het Bijzonder Hoogleraarschap in

het Internationaal Management, beide in

de Faculteit der Economische Wetenschappen van

de Rijksuniversiteit Limburg

op vrijdag 15 mei 1987

door

Ir. Dr. Geert Hofstede 



\section{VOLKSKARAKTER EN NATIONALE CULTUUR}

Het toekennen van collectieve eigenschappen aan de eigen en aan andere groepen en volken is vermoedelijk zo oud als de volken zelf. ledere Belgische scholier leert het citaat van Julius Caesar in zijn boek over de Gallische oorlog, waarin staat dat van de drie soorten Galliërs de Belgen de dapperste zijn. Wij kennen allemaal het begrip 'volkskarakter', hoewel dat begrip een twijfelachtige wetenschappelijke status heeft. Wanneer een persoon P een uitspraak doet over het karakter van een volk of bevolkingsgroep $\mathrm{V}$-zijn eigen of een ander- vertelt die uitspraak ons altijd iets over $\mathbb{P}$, maar moeten we nog maar af wachten of hij ook werkelijk geldige informatie over $V$ bevat.

Geldige informatie over een volk is informatie, die beschrijvend is en niet be- of veroordelend; die uit meerdere, onafhankelijke bronnen verifieerbaar is; die opgaat voor zo niet alle, dan toch een statistische meerderheid van de leden van het bedoelde volk; èn die discrimineert, dat wil zeggen dat hij aangeeft waar dit volk zich van andere onderscheidt. Als aan deze vier voorwaarden niet voldaan kan worden -en dat is bij uitspraken over volkskarakters vaak het geval geweest- kunnen we het hele begrip beter laten rusten. Ondanks een glorieus verleden met wortels in de klassieke oudheid en met 18e eeuwse beoefenaars als Montesquieu en Kant (1), is de beschrijving van volkskarakters de laatste dertig jaar in diskrediet geraakt. Pas in dit decennium neemt de belangstelling erin weer toe, onder de invloed van een stijgende behoefte aan internationale samenwerking, maar ook door de beschikbaarheid van betere en meer systematisch verzamelde informatie. In plaats van de term 'volkskarakter' wordt ook wel 'nationale cultuur' gebruikt, cultuur in de brede, antropologische zin van het woord. Persoonlijk prefereer ik deze laatste term, ondat hij minder belast is en meer objectiviteit suggereert.

Het thema van deze voordracht is: de Nederlanders als volk. Ik zal in het bijzonder trachten aan te geven waar Nederlanders zich van andere wereldburgers onderscheiden ten aanzien van gezondheid, recht en economie. Dit, omdat het de vakgebieden zijn die momentel aan deze uni- 
versiteit worden beofend; en al zitten we dan aan de uiterste rand van Nederland, wij horen toch bij de Nedlerlandse cultuur. De keus van thet onderwerp "Gevolgen van het Nederlanderschap' is mede bepaald door mijn leeropdracht "Internationaal Management". Ik geloof namelijk dat effectief internationaal functioneren bevorderd wordt door nationale zelfkennis. Waar je ook bent ter wereld, je Nederlanderschap neem je altijd mee, en het bepaalt zowel hoe jij op anderen reageert, als hoe anderen reageren op jout.

\section{DE NEDERLANDSE CULTUUR: ACHT ROLLEN}

Laten we beginnen met een aantal algemene kenmerken van de Nederlandse cultuur. De informatie hierover komt in de eerste plaats uit geschriften van buitenlandse waarnemers gedurende de laatste vijf eeuwen. Deze zijn weliswaár stuk voor stuk subjectief gekleurd, maar tezamen genomen bieden ze toch een aantal duidelijke punten van overeenstemming. Verder geven deze uitspraken een historische diepte aan de beschrijving. Cultuur komt niet zomaar uit de lucht vallen: het bestaat uit die dingen, die elke generatie van de vorige heeft geleerd. Cultuurverschillen tussen landen hebben vaak diepe historische wortels: zo onderscheiden bijvoorbeeld de culturen wan landen die ooit deel uitmaakten van het Romeinse rijk zich ook vandaag nog aantoonbaar van dié van landen die destijds barbaars bleven (2). In de tweede platats komt mijn informatie over de Nederlandse cultuur uit recent vergelijkend statistisch materiaal, zowel uit internationale opinie-onderzoeken, als uit internationale statistieken die wijzen op collectieve gedragsverschillen, en die door diverse internationale instanties worden gepubliceerd.

De cultuur van een volk omvat stelsels van waarden, dat wil zeggen van overtuigingen over wat goed is en wat kwaad, mooi en lelijk, rationecl en irrationeel, moreel en immoreel, enzovoort. De uitspraken van buitenlanders over Nederland weerspiegelen de vaak afwijkende waarden uit hún culturen, waaraan zij Nederland meten. Bepaalde eigenschappen wan de Nederlanders worden door de éne buitenlander als goed en door de andere als slecht genoemd. Voor mijn analyse is het belangrijkste dát zij diè eigenschappen noemen. Ik zal proberen het goed of slecht terzijde te laten, en beschrijvend te werk te gaan. Bij 
deze beschrijving zal ik niet uitgaan van een opsomming van eigenschappen die Nederlanders verondersteld worden gemeen te hebben. Culturele eigenschappen zijn niet los verkrijgbaar. Ze vormen een samenhangend geheel, waar men niet naar believen een onderdeel uit kan weglaten of aan toe kan voegen. Ze vormen een geheel dat onder sommige omstandigheden positieve, onder andere omstandigheden negatieve gevolgen kan hebben voor de lotgevallen van een volk, en voor het beeld dat het bij anderen oproept.

Om die samenhang te benadrukken wil ik u de Nederlander in intemationaal perspectief beschrijven als een combinatie van sociale rollen. ledere rol omvat een aantal eigenschappen; iedere rol is zowel goed als slecht, goed voor sommige doeleinden, maar slecht voor andere. De Nederlander -hij of zij-is dan een persoon die de wereld in én of meer van de volgende acht sociale rollen tegemoet treedt: dominee, huisvrouw, verpleegster, herbergier, reiziger, handellaar, burger en boer. Dus niet in een aantal rollen die meer voor andere landen zouden kunnen gelden: edelman, bedelman, dokter, pastoor, enzovoort, of soldaat, handwerksman, dandy en heilige.

De dominee zit in vele Nederlanders (3) of Nederlandsen. Menno ter Braak schreef zijn 'Afscheid van Domineesland'. De dominee is een Calvinist, zelfs als hij of zij katholiek is, joods, humanist, communist of agnost (4). De dominee wijst anderen terecht om hun eigen bestwil en doet dat ook over de grenzen heen. De Italiaanse journalist Luigi Barzini schrijf: "The Dutch see themselves as the only sane people in an insane world they defend all moral causes' (5) -en de Zwitser Emest Zahn, die hoogleraar in Amsterdam geweest is, noemt ons 'das einmisschungssüchtigste Volk der Erde' (6). De Engelse vertaling van een 'dominee' is "a Dutch uncle'. 'Talking to someone like a Dutch uncle' wordt in de Oxford Dictionary gedefinieerd als 'lecturing him paternally", een veelzeggende uitdrukking die al tenminste sinds het begin van de $19 \mathrm{e}$ eeuw deel uitmaakt van het Britse taaleigen. Zelf heb ik een vergelijkend onderzoek door middel van opiniconderzoeken gedaan onder 64 nationale dochtermaatschappijen van de multinational IBM, waarbij telkens mensen in exact dezelfde functies naast elkaar werden gezet, die alleen in nationaliteit verschilden. In dit internationale gezelschap scoorden de Nederlanders èn de Scanclinavièrs extreem in twee opzichten: sterk individualistisch, dat wil zeggen go- 
neigd het individuele belang en de individuele mening te laten gelden, èn tegelijk sterk feminien, dat wil zeggen verzorgend, gericht op het helpen wan de zwakke en het handhaven van warme persoonlijke relaties met anderen (7). We herkennen hierin de dominee, die het beste met de ander vór heeft, maar wel precies weet wat goed is voor die ander. Ter vergelijking: de Amerikanen scoorden in dit onderzoek ók zeer individualistisch, maar masculien, dat wil zeggen gericht op prestatie en wedijver, op bewondering voor de sterke in plaats van steun voor de zwakke (8).

De tweede Nederlandse rol is die van huiswrouw; ook als zij een man is. Het werk van de huiswrouw is onder meer gericht op gezelligheid een onvertaalbaar Nederlands woord-en op het schoonhouden van de woning. Volgens de cultuurhistoricus Huizinga (9) is het NoordNederlands de enige taal die dezelfde term, 'schoon', gebruikt voor het esthetisch bewustzijn, ên woor de afwas. Zelfs de Vlamingen doen dat niel. Over de zindelijkheid van de Nederlandse woningen wordt al in 1549 door een Spaanse reiziger gerapporteerd (10). Ook Edmondo de Amicis, een Italiaans literator die in 1873 een bekend boek over ons land deed werschijnen, wertelt hierover, maar merkt tegelijk op dat deze zindelijkheid niet samengaat met persoonlijke hygiëne (11). De moderne vorm van huisvrouwelijkheid is zorg voor het millieu, een probleem dat hoog scoort in de publieke opinie in Nederland (12) 'terecht', zeg je als Nederlander.

De derde rol is die van verpleegster of, zo u wilt, verpleger. De Nederlander is gericht op het helpen van de zwakke, hulpvaardig, vrijgevig, en vredelievend. In onze eigen samenleving hebben wij een welvaartsstaat opgebouwd die in effectiviteit en omvang van de voorzieningen alleen door die van de de Scandinavische landen wordt gee̊venaard ondanks het feit dat deze voorzieningen onder onze huidige regeringen aan een zekere afbraak onderhevig zijn. Internationaal zijn wij recordhouders in ontwikkelingshulp, gemeten naar het Bruto Nationaal Produkt: op dit moment meer dan vijf miljard gulden. De Nederlanders "overtreffen in liefdadigheid alle volken van Europa', schreef de Amicis al in 1873 (13). Zelfs in de 17e eeuw was Nederland in vergelijking tot andere landen al een 'welvaartsstaat' (14). Vredelievend en antimilitaristisch zijn Nederlanders ook sinds eeuwen geweest; militaire helden hebben in wergelijking met het buitenland nooit in hoog 
aanzien gestaan, zelfs Michiel de Ruyter in zija tijd niet (15). In 1981 is een vergelijkend onderzoek uitgevoerd naar fundamentele waarden in negen Europese landen via interviews met een representatieve steekproef uit de bevolkingen. In dit onderzoek, waarvan de resultaten briljant zijn geanalyseerd door de Fransman Jean Stoetzel, scoren de $\mathrm{Ne}$ derlanders en de Denen het laagst op "vertrouwen in het leger" (16). Zowel de rol van de huisvrouw als die van de verpleegster sluiten aan bij de extreme score van de Nederlandse IBM-steekproef op de dimensie die ik 'femininiteit' heb genoemd. Het Nederlandse antimilitarisme geeft de meeste aanstoot in landen, die op deze dimensie juist masculien scoren, zoals Italiè, waar de eerdergenoemde Luigi Barzini zich aan ons ergert, en de Verenigde Staten. In dat laatste land bedacht de politieke journalist Walter Laqueur de term "hollanditis" voor wat hij beschouwde als morele slapte (17); iedere cultuur ziet de moraal natuurlijk aan de eigen kant staan. Overigens is het publieke vertrouwen in de Amerikanen bij het Nederlandse en ook het Belgische publiek blijkens onderzoek van de E.E.G. in de laatste jaren ook niet hoog (18), de keerzijde van hetzelfde waardenconflict. Het toppunt van femininiteit in Nederland is de oprichting van een comité om de prestatie-gerichte masculiene Olympische Spelen buiten ons land te houden. Zoiets zou nauwelijks in een ander land ter wereld denkbaar zijn, en wordt elders dan ook niet begrepen.

De herbergier of herbergierster als vierde rol slaat op onze gastvrijheid tegenover refugiés, tenminste sinds de periode na het jaar 1492, toen een deel van de Iberische joden in Nederland onderdak vond. Evenmin als de meeste herbergiers zijn wij van onze gastvrijheid slechter geworden: afstammelingen van immigranten hebben de Oostindische Compagnie, Philips, Unilever en Akzo mee opgericht. In het IBMonderzoek scoren de Nederlanders ten opzichte van thun collega's in Duitsland, Frankrijk en Spanje lager (maar niet extreem laag) op een dimensie die ik met 'onzekerheidsvermijding' heb aangeduid, en die onder andere samengaat met intolerantie, met een angstgevoel: 'wat anders is, is gevaarlijk'. De meeste Nederlanders denken niet zo. Een Nederlandse reaktie is: 'wat anders is, is gek'. Dat kan hinderlijk zijn voor de ander, maar hij of zij wordt wel getolereerd. De combinatie van tolerantie met feminiene zorg voor de zwakke heeft tot ons internationale herbergierschap geleid. In eigen land zie je deze praktische tolerantie belichaamd in typisch Nederlandse politieke constructies als 
de verzuiling (19) (met de onvertaalbare Nederlandse term 'andersdenkenden') en het pluriforme omroepbestel.

De reiziger of reizigster als vijfde rol betreft ons wereldburgerschap. Nederlanders zijn weinig patriottisch en chauwinistisch, en in vergelijking met anderen sterk internationaal georiënteerd. Edmondo de Amicis was in 1873 stomverbaasd over de hoeveelheid wereldnieurws in de Nederlandse kranten -ze waren even goed over de Italiaanse politiek geïnformeerd als de Italiaanse (20). Ook vandaag nog besteden de $\mathrm{Ne}$ derlandse pers èn televisie relatief meer aandacht aan het buitenland dan in de meeste Europese landen het geval is. Ons geringe patriottisme blijkt onder andere uit het waardenonderzoek van Stoetzel, anno 1981, waarover ik zoëven sprak: samen met de Duitsers scoren de Nederlanders hierin het laagst op 'trots in eigen nationaliteit' (21). Kankeren op het eigen land is een favoriet tijdverdrijf, waaraan zowel onze grootindustriëlen als onze kleinburgers meedoen. Ik geloof overigens dat het daarbij om een vorm van apenliefde gaat: we drukken op deze manier onze verknochtheid uit, en we zijn er volstrekt niet van gediend als een buitenlander ons in onze kritiek op Nederland meent te moeten bijwallen.

De zesde rol, die van handelaar of handelaarster, is in elk geval sinds de $17 \mathrm{e}$ eeuw steeds door Nederlanders met relatief succes vervuld. Daarbij stonden wij als betrouwbaar te boek, maar tegelijkertijd als geldzuchtig (22). Ik vermoed overigens dat deze laatste aanduiding in principe ook voor de meeste van onze handelspartners gold, maar dat wij gewoon wat meer succes hadden. Een feminien waardenstelsel, vredelievend en gericht op relaties met personen, is in de handel een voordeel. De Nederlander vervulde zijn rol van handelaar daarbij wel in concurrentie met die van dominee, wat tot merkwaardige paradoxen voerde. Waar nodig, wist de dominee te rechtvaardigen dat bepaalde volken van de nationale hulpvaardigheid werden uitgesloten, en tot handelsobjekten gemaakt. Dit maakte bijvoorbeeld de Nederlandse betrokkenheid bij de internationale slavenhandel in de $17 \mathrm{e}$ tot de $19 \mathrm{e}$ eeuw mogelijk, en vormen van uitbuiting in ons eigen koloniale beleid. Andere landen deden in dit opzicht niet voor ons onder, maar probeerden het niet door dominees te laten rechtvaardigen. Multatuli portretteerde in zijn 'Max Havelaar' uit 1860 ene dominee Wawelaar, die beschouwd kan worden als het prototype. Zeer recent is het 
Rhemrev-rapport uil 1903 boven water gekomen, dat ondubbelzinnig aantoont hoezeer respektabele Nederlanders zich in Nederlands-Indie te buiten gingen (23). Tot op de dag van vandaag is het Nederlandse commercieel-calvinistische denken over andere rassen terug te vinden in de Zuid-Afrikaanse apartheidsfilosofie.

De zevende en achtste rol zijn die van burger (ook burgeres, of burgerjuffrouw) en boer of misschien nog meer, boerin. Hiermee wil geduid zijn op onze vrijheidsliefde, ons egalitarisme, onze afkeer van praal, maar ook op onze middelmatigheid onze botheid en onbeleefdheid (24). In het IBM-onderzoek scoren de Nederlanders relatief laag (maar niet extreem laag) op de dimensie 'machtsafstand'" de mate waarin een samenleving ongelijkheid normaal vindt. Onze samenleving was en is ongelijk, maar minder ongelijk dan sommige andere, en we zijn strijdbaar tegenover hen die ons ongelijker willen maken (25). De Duitse bezetting heeft ons en bijvoorbeeld de Denen fundamenteler geraikt dan het de Belgen en Fransen gedaan heeft (26); onze katholieken verzetten zich sterker tegen hiërarchisch ingrijpen van Rome dan andere. Daartegenover staat dat deze gelijkheidsideologie kan leiden tot wlakheid en kleurloosheid in onze samenleving, en tot gebrek an respekt voor andleren, aan wat die anderen zien als gewenste manieren. Over het gedrag van de Nederlander aan het stuur van een auto beklagen zich sinds tientallen jaren vele buitenlanders (27). Burgers die door afstamming of opleiding iets minder gelijk zijn dan anderen worden regenten: men vindt ze vooral in onze politieke partijen, van links tot rechts, onze besturen, onze Raden van Commissarissen. Regenten zijn nietheroïsche leiders: men merkt het zelden als de éen door de ander vervangen wordt. Ze staan al afgebeeld op de grote schilderijen van Rembrandt: zij vormen de Nachtwacht van onze cultuur.

Wanneer men zich in cultuurverschillen tussen landen verdiept, rijst altijd de vraag naar hun oorsprong. Favoriet bij vele schrijuers sinds de oudheid is het, om cultuurverschillen uit klimatverschillen te verklaren. De Nederlander is dan saai, gevoelloos en egalitair omdat zijn of haar land zo vochtig, eentonig en vlak is. Dit soort verklaringen, toegepast op een enkel land, is onverifieerbaar en daarmee waardeloos. Als we echter over gegevens van een aantal landen beschikken, kunnen verbanden tussen culturele en klimatologische gegevens statistisch worden getoetst. Met de scores van 40 landen op de vier dimensies van 
het IBM-onderzoek (Individualisme/Collectivisme, Masculiniteit/Femininiteil, Onzekerheidsvermijding en Machtsafstand) heb ik dat gedaan, en dan blijkt dat machtsafstanden afnemen naarmate een land verder van de evenaar ligt, een ruwe maat voor de gematigdheid van zijn klimaat (28). Op die manier is er toch iets waar van het verband tussen ons klimaat en ons egalitarisme. Voor de andere drie dimensies gelden dergelijke verbanden overigens niet. Het ligt ook voor de hand culturele verschillen uit de geschiedenis te verklaren. Als de Nederlander van vandaag op anderen overkomt als een combinatie wan dominee, huisvrouw, verpleegster, herbergier, reiziger, handelaar, burger en boer is dat mede plausibel omdat vele Nederlanders honderden jaren lang van eén van deze acht rollen hun hoofdberoep hebben gemaakt, méêr dan mensen in andere landen. Geschiedkundige verklaringen worden verifieerbaar door internationale vergelijking, als we kunnen aantonen dat configuraties van landen met een gemeenschappelijke historie ook bepaalde culturele trekken gemeen hebben. In het IBM-onderzoek vormt Nederland één cultureel cluster met Noorwegen (onze naaste culturele zuster), Denemarken, Zweden en Finland: Noordwest-Europese landen met een agrarisch-zeevarende inslag, die ondanks een geringe bevolking hun onafhankelijkheid tegenover grotere landen hebben weten te bevechten. Eén gemeenschappelijke factor in onze historie is de Duitse Hanze, een handelsverbond van vrije Noordwest-Europese staten dat vooral in de $14 \mathrm{e}$ en $1.5 \mathrm{e}$ eeuw heeft gebloeid. Het valt aan te nemen dat deze handelsrelaties cultuurbevestigend hebben gewerkt, maar op basis van een al aanwezig cultureel potentieel (29). Er heeft ongetwijfeld een groot aantal factoren samengewerkt over honderden of zelfs duizenden jaren om onze cultuur te maken tot wat deze vandaag is, waarbij volken met min of meer gelijke uitdagingen van klimatologische en geschiedkundige aard zich ook gedeeltelijk hetzelfde hebben ontwikkeld.

\section{NEDERLANDSE CULTUUR EN GEZONDHEID}

Nadat we de Nederlandse cultuur in grote lijnen hebben beschreven, kunnen we nu afdalen in de vakgebieden gezondheid, recht en economie. Allereerst de gezondheid. Wij komen hier de Nederlander in de eerste plaats tegen in de rol van verpleegster of verpleger. onze verzorgende mentaliteit. Ernest Zahn heeft opgemerkt, dat het woord 
'welzijn' in de Nederlandse taal een latent-religieuze bijklank heeft (30): de verpleegster als dominee. Eén van de meetbare aspekten van de gezondheidszorg in een land is het aantal verplegenden per arts. Er zijn landen waar het aantal artsen het aantal officièle verplegenden overtreft, en andere waar tegenover één arts bijna tien verplegenden staan. Het aardige van deze maat is dat hij onafhankelijk is van het ontwikkelingsniveau van een land: ook in een arm land waarin van beide groepen te weinig zijn, blijft de verhouding tussen aantal verplegenden en aantal artsen een index voor de manier, waarop de schaarse middelen verdeeld zijn. De Wereldbank publiceert sinds een aantal jaren voor de meeste landen cijfers van de aantallen inwoners per arts en per verplegende, en als we die op elkaar delen, krijgen we de bedoelde index (31). Het aantal verplegenden per arts bli.jkt nu in sterke mate samen te hangen met de door mij in het IBM-onderzoek gemeten cultuurdimensie onzekerheidsvermijding, en wel met negatief teken: hoe groter de onzekerheidsvermijding, des te meer artsen; hoe kleiner, des te meer verplegenden (32). Onzekerheidsvermijding gaat samen met een geloof in de expert, dat is de arts, en een wantrouwen in de leek, in dit geval de verplegende. Nederland, zoals a zich misschien herinnert, scoort in het IBM-onderzoek beneden het gemiddelde op onzekerheidsvermijding; het scoort dienovereenkomstig boven het gemiddelde op verplegenden per arts, namelijk op basis van cijfers uit 1980, ruim vier verplegenden per arts.

Gezondheidszorg en welzijn hangen natuurlijk niet alleen af van aantallen gezondheidswerkers, maar ook van wat die mensen doen en hoe ze zijn toegerust. Een universele index voor het welzijnsmiveau van een land is ontworpen door de Amerikaan Morris D. Morris. Deze is samengestelld uit drie componenten:

- de overlevingskans van zuigelingen gedurende het eerste levensjaar;

- de verwachte levensduur van hen die het eerste levensjaar volbracht hebben;

- en het percentage van de bevolking dat kan lezen en schrijuen.

Dus twee medische componenten en eén sociale. Morris heeft zijn index berekend woor 150 landen (33). Uiteraard is hij gecorreleerd met het nationale inkomen per hoofd van de bevolking: rijkere landen hebben in het algemeen een hoger welzijnsniveau (34). Verschillen in welvaart tussen llanden (in nationaal inkomen) verklaren echter maar iets meer dan de helft van de verschillen in welaijn, en met name 
verklaren zij niet de verschillen in welzijn tussen de rijkere landen. Voor de rijkste 19 landen in het IBM-onderzoek hangt hel welzijnsniveau volgens Morris niev meer af van de welvaart, maar van de mate van femininiteit van hun cultuur (35). Rijke, feminiene landen als de Scandinavische en Nederland scoren dan ook zeer hoog op de Morrisindex. Dit betekent dus lage kindersterfte, hoge levenswerwachting, hoog niveau van alfabetisme. De kindersterfte in Nederland was overigens in het begin wan de $19 \mathrm{e}$ eeuw nog de hoogste in West-Europa; pass sinds circa 1880 , met de komst van waterleidingsbedriven, begon deze te dalen (36). Het alfabetisme in Nederland lag al in de $16 e$ eeuw relatief hoog; als een van de redenen woor het succes van de Reformatie hier wordt genoemd dat zoveel mensen de Bijbel zelf konden lezen (37). Het welzijn in de rijke, feminiene landen wit zich ook in de gemiddelde lichaamslengte. Op dit punt is Nederland Noorwegen en Zweden voorbijgestreefd: op basis van metingen van onze huidige 16jarigen zijn we bezig het gemiddeld langste volk ter wereld te worden (38). Lange mensen komen ook in andere volken voor, het meest in de hogere sociale klassen, maar ons hoge gemiddelde berust op de goede voeding en verzorging van juist de gewone jongen of het gewone meisje. De lichaamslengte is daarmee een fysieke meting van een culturele waarde.

Welzijn is ook subjectief meetbaar. Vergelijkende onderzoekingen in de laatste twintig jaar hebben aangetoond dat Nederlanders in vergelijking tot mensen uit andere landen zeer tevreden zijn met hun leven (39). Ook ons hoge werkeloosheidspercentage, de milieuverontreiniging of de criminaliteit kunnen hier niets aan veranderen. Volgens de statistieken voldoen wij dus aan de omschrijving die een Franse diplomaat in 1921 gaf: "le pays du petit bonheur' (40).

Cultuur bepaalt niet alleen hoe wij leven, mar ook hoe wij sterven. Het wertband tussen cultuur en doodsoorzaak ligt het meest voor de hand in het geval van zelfdoding. Eén van de grondleggers van de Franse sociologie, Emile Durkheim, heeft al in 1897 aangetoond dat zelfmoordpercentages in de tijd zeer stabiel zijn en van land tot land en groep tot groep verschillen (41). De Ier Richard Lynn heeft in 1971 laten zien dat doodsoorzaken per land in combinatie voorkomen. Op basis van een factor-anallyse heeft hij een index ontwikkeld die hij 'neuroticisme" noemt, en die positief gelieerd is met zelfdoding, dood 
door verkeersongevallen en door cirhose van de lever als gevolg van overmatig alcoholgebruik, maar negatief met sterfgevallen door aandoeningen van de kransslagader (42). Lyrn's neuroticisme-index blijk nu sterk samen te hangen met de index voor onzekerheidsvermijding uit mijn IBM-onderzoek. Sterke onzekerheidsvermijding dutdt op een hoog miveau van nerveuze spanning en emotionaliteit, en dit uit zich blijkbaar in méer zelfdoding, verkeersongevallen, en alcoholmisbruik, maar in relatief minder hartinfarcten. Nederland, iets beneden het gemiddelde op onzekerheidsvermijding, scoort ook beneden het gemiddelde op Lymn's neuroticisme. Onze zelfmoordpercentages zijn weliswaar stijgende, maar in vergelijking mel de meeste Europese landen nog steeds laag. Ze varieren bovendien sterk per bevolkingsgroep. In een studie over de jaren 1931-1952 werden extreem hoge percentages gevonden voor kleine protestantse secten -groepen met sterk onzekerheidsvermijdende en schuldbelaste subculturen- maar lage voor katholieken, gereformeerden en onkerkelijken (43).

\section{NEDERLANDSE CULTUUR EN RECHT}

Het recht is evident gebonden aan de nationale cultuur. De geschreven wet komt uit de cultuur voort, maar houdt deze ook mee in stand. De rechtswetenschappen bieden zowel ruimte aan de dominee als aan de handelaar in ons: de eerste schrijft de wetten en de tweede vindt wegen om ze te ontduiken. Nederlandse rechtsgeleerden, sinds Philips van Leiden en Hugo de Groot, hebben zich veel met vragen van internationaal recht bezig gehouden (44). Buitenlanders accepteren de dominee in de gedaante van intemationaal rechtsgeleerde blijkbaar gemakkelijker dan in andere gedaanten. Onze nationale wetgeving wordt in verhouding tot andere landen relatief soepel gehanteerd: wij zijn een very permissive society. In het negen-landen-onderzoek van Stoetzel uit $\mathbf{1 9 8 1}$ is een index voor permissiviteit ontwikkeld waarop Nederland hoog scoort; over de negen landen blijkt deze samen te gaan met de femininiteitsscore uit het IBM-onderzoek" moeders vinden meér goed dan vaders. Recht heeft daarnaast uiteraard iets te maken met onzekerheidsvermijding: wetten zijn ến van de manieren waarop een samenleving onzekerheid uit de weg gaat. In landen met cen sterke onzekerheidsvermijding volgens het IBM-onderzoek bestaat bijwoorbeeld het overtheidsapparaat meér uit juristen: in Duitsland bleek omstreeks $197065 \%$ van de hogere ambtenaren een rechtengraad te hebben, in Engeland $3 \%$. 
Nederland zat daartussen met $39 \%$ (45). Hoe meer in een cultuur op zeker wordt gespeeld, des te meer laat men er de zaken door juristen behartigen.

Een sprekend voorbeeld van de invloed van cultuur op wetgeving wormt de reaktie van verschillendle West-Europese landen op de oliecrisis van 1973. Deze leidde in alle landen tot een discussie over het al of niet invoeren van snelheidslimieten op autobanen. De limieten die uiteindelijk werden ingevoerd, varieerden van minder dan $100 \mathrm{~km} / \mathrm{uur}$ in Ierland, Noorwegen en Finland, tot oneindig (geen limiet) in Duitsland. In Nederland werd $100 \mathrm{~km} /$ uur gekozen. Wanneer wij van 14 West-Europese landen de ingevoerde snelheidslimieten op een rij zetten, blijkt hun rangorde significant te correleren met mijn nationale onzekerheidsvermijdingsscore. Niet zoals u zoudt denken negatief (bij grotere onzekerheidsvermijding een lagere limiet), maar positief. Het relatief aantal verkeersdoden is ook positief gecorreleerd met onzekerheidsvermijding, zodat wij het paradoxale verschijnsel zien dat de landen die vó́r de invoer van de limiet de meeste verkeersslachtoffers hadden, de hoogste limieten hanteerden. De keus van de limiet werd niet bepaald door overwegingen wan verkeersveiligheid, maar van haast. Onzekerheidsvermijding, zoals we zagen gecorreleerd met neuroticisme, is een maat voor het nationaal haastgevoel: de relatieve prioriteit die men hecht aan het sparen van tijd ten opzichte van het sparen van levens (46). Nu zult u mij tegenwerpen dat althans in Nederland de limiet van $100 \mathrm{~km} /$ uur niet wordt gerespecteerd. Dit is inderdaad het ge$\mathrm{val}$, maar ik had het over de formele wetgeving, niet over de naleving ervan. Onze successievelijke overheden hebben de ingevoerde limiet zelf niet serieus genomen. Ik betreur dit ten zeerste, want door niet te controleren maakt de overheid ons allen tot kleine criminelen op de autobaan. I $\mathrm{k}$ ben er trouwens in het algemeen van overtuigd dat de toename van de zogenaamde kleine criminaliteit in onze samenleving niet het gevolg is van een normverschuiving, dus een cultuurverandering, maar van het ondoordacht bezuinigen on vroeger normale controlemaatregellen (47). De samenleving lijat hier dubbel onder: noodzakelijke spelregels worden geschonden, en zij die vroeger controleerden worden nu toegevoegd aan het leger van werklozen.

De huidige discussie in Nederland over de invoering van de legitimatieplicht voor burgers is een meer actueel voorbeeld van de relatie tussen cultuur en recht. Op dit moment kennen er van 14 West-Euro- 
pese landen zeven de legitimatieplicht, zeven niet. In het cerste geval moet de burger te allen tijgle een idlentiteitskaar bij zich dragen en die op verzoek van de autoriteiten tonen, anders is hij of zij strafbaar. In het weede geval hoeft de burger zijn bestan tegenover de autoriteiten niel te rechtvaardigen, al draagt hij of zij vaak toch wel kaarten bij zich in verband met bijwoorbeeld financielete transacties. De scheidsiijn fussen landen met en zonder legitimatieplicht is wrijwel exact gelijk aan die tussen sterke en $z$ wakke onzekerheidsvermijding uit het IBMonderzoek. Als wij in Nederland nu een legitimatieplicht krijgen, betekent dat dat we verschuiven van de ene cultururgroep in de richting van de andere ( 48 ).

\section{NEDERLANDSE CULTUUR EN ECONOMIE}

Economen zinn de dominees onder de handelaren, en voor hen is Nederland dus een paradijs. Het is woor mij dan ook cen voorrecht om hier aan een economische faculteit verbonden te zijn. Als hoogleraar Internationaal Management binnen deze faculteit verheug ik mij er op dat wij ook de reiziger in ons hebben. Ten opzichte van onze buurlanden onderscheidt zich onze cultur vooral door onze feminimiteit. Onder condities van vrije intemationale concurrentie -een relatief nieuw fenomeen in de wereld, en ook nu nog voondurend bedreigd door protectionisme-zal een land zich het besie kunnen handhaven op die economische terreinen waartoe het cuturele affiniteit bezit. Voor een masculien land is dit wooral produktie van goederen: goed, veel en efficient. Voor een feminien land als Nederland is dit dienstverlening waarbij de relatie met de klant voorop staat: handel, bankwezen, advisering, hulpverlening, transport; maar ook de voortbrenging van levende produkten, die gekweekt, dat is vertroeteld, en niet geproduceerd worden: hoogwaardige landbouw, bio-chemie, bio-industrie. Ik vertel hierbij niets nieuws, want al deze dingen hebben we al en op al deze terreinen kunnen we redelijk concurrerend meekomen. In de produktie van goederen, zoals machines, schepen, apparaten, concurreren wij het beste daar waar een blijvende relatie met een klant nodig is, zodat ons produkt een verkapte dienst is -hardware, die men vanwege onze software koopt.

Nederland is internationaal gezien een rijk land. Nationale welvaart 
gemeten in Bruto Nationaal Produkt per inwoner is hoog gecorreleerd met de index voor individualisme in het IBM-onderzoek. De causaliteit gaat daarbij van welvaart naar indlividualisme, niet andersom. Economische groei is niet met ét van mijn vier indices gecorreleerd, maar wèl met een vijfde index die onlangs door mijn collega Michael Bond van de Chinese Universiteit in Hong Kong is geidentificeerd in de antwoorden van studenten uit 22 landen, waaronder Nederland, op een oorspronkelijk Chinese vragenlijst. Deze vijfde dimensie heeft hij "confuciaans dynamisme" genoemd: het stelt de confuciaanse waarden van spaarzaamheid en volharding tegenover de eveneens confuciaanse waarden van traditie en het 'redden van je gezicht". De landen wan Oost-Azie scoren hoog op confuciaans dynamisme èn op economische groei, en deze twee zijn dan ook sterk geconreleerd (49). Dit illustreert hoe nationale waarden onder gunstige uitwendige omstandigheden het verschil kunnen uitmaken tussen landen die zich wèl en niet ontwikkelen. Overigens scoorden van de Westerse landen de Nederlandse studenten op deze dimensie het meest Aziatisch: zuinig en volhardend. Wij zijn al vaker de Chinezen van Europa genoemd.

\section{TENSLOTTE}

De gegeven voorbeelden uit de vakgebieden van gezondheid, recht en economie tonen aan dat nationale cultuur op tal van terreinen in de maatschappij een relevant gegeven is, en ook dat men een scherper besef ontwikkelt van de eigen nationale cultuur door over de grenzen te kijken. Welke Nederlandse universiteit is gunstiger gevestigd om over de grenzen te kijken dan die van Maastricht, waar het buitenland zó nabij is? Dit houden wij ook onze toekomstige studenten voor, van wie wij hopen dat zij naar Maastricht zullen komen om hier Internationaal Management te studeren. Als bonus bieden wij daarbij de Limburgse regionale cultuur, die voor de Noord-Nederlander exotische kanten heeft, zodat hij of zij zich al een beetje in het buitenland kan wanen.

Formeel bekleed ik aan deze universiteit twee gedeeltelijke leerstoelen. De ene is een Hoogleraarschap in de Vergelijkende Cultuurstudies van Organisaties, waarop ik als 6 én van de laatsten nog door H.M. de Koningin benoemd ben. Nu gebeurt dat door het College van Bestuur. 
Ik dank Hare Majesteit cerbiedig en ik dank ook het College van Bestuur dat Haar in deze geadviseerd heeft. De andere leerstoel is een Bijzonder Hoogleraarschap namens de SWOL de Stichting Wetenschappelijk Onderwijs Limburg. Hiervoor dank ik het Bestuur van de SWOL. Tot het instellen van deze bijzondere leerstoel is de SWOL mede in staat gesteld door een bijdrage van IBM Nederland; bij alles wat ik aan IBM te danken heb, voegt zich nu deze bijdrage, waarvoor ik de direktie van IBM Nederland bijzonder erkentelijk ben.

Aan het eind van een oratie mag men persoonlijk worden. Het is vandaag iets meer dan 20 jaar geleden dat ik aan de Rijksuniversiteit Groningen promoveerde tot Doctor in de Sociale Wetenschappen. Mijn promotor was professor Herman Hutte. Herman, jij bent er in geslaagd een ingenieur in een psycholoog te veranderen; dat is zoiets als water veranderen in wijn. Jouw rolopvatting als promotor is voor mij een model in de relatie met mijn eigen promovendi. Wat ik over cuituur gezegd heb berust vaak op collectieve ontdekkingen tijdens de omzwervingen van ons gezin in andere landen. Wij zijn het soort individualisten dat het prettig vindt dingen samen te doen. Dat is, denk ik, ook zeer Nederlands. Ik wind het een voorrecht dat het ritueel van vandaag door mijn familie wordt bijgewoond. Wat ik voel is door Willem Elsschot uitgedrukt in de laatste regels van zijn roman 'Kaas". Wie het boek kent, begrijpt wat ik bedoel.

Dames en Heren, Nederlanders en Andersdenkenden, dank u allemaal voor uw aanwezigheid. 
1. Zie b.v. Phillips, 1985:13; Chorus, 1964:72; Stoetzel, 1983: 257.

2. Hofstede, $1980: 127,179,314$

3. Chorus, 1964:93

4. Barzini, 1983:207; Gortzak, 1985. Zie ook Rentes de Carvalho, 1982:92, over de voor hem als Portugees loodzware geloofsbelleving van de Nederlander.

5. op. cit. 212

6. Zahin, 1984:176. Hij ontleent deze opvatting aan een Belgische auteur, H. van Pelt. De studie van Voorhoeve (1979) over de Nederlandse internationale politiek heet Peace, Profits and Principles'.

7. Hofstede, 1980:222, 279; 1983

8. Hofstede, 1985. De in Nederland docerende Amerikaan Phillips (1985:18) noemt Nederland juist collectivistisch, maar doelt daarmee op trekken die ik met' 'feminien" heb aangeduid.

9. Huizinga, 1946:23. Hij noemt als contrast 'een schoon boordje'; Chorus, 1964:51

10. Parker, 1985:20

11. de Amicis, 1985:17

12. B.v. Abrams, 1971:108

13. de Amicis, 1985:140

14. Zahn, 1984:65 (naar Huizinga)

15. Chorus, 1964:67

16. Stoetzel, 1983:64. Het Nederlandse deel wan het onderzoek stond onder leiding van Prof. R.A. de Moor uit Tilburg.

17. Elsevier's Magazine, 1987, 43, 1:39

18. Inglehart \& Rabier, 1983:38

19. Goudsblom, 1967

20. de Amicis, 1985:135

21. Stoetzel, 1983:23

22. Chorus, $1964: 163$

23. Kousbroek, 1987

24. Zie b.v. Chorus, 1964:59; de Amicis, 1985:68; de Baena, 1966:66 e.v.; Meertens, 1950:12; Pottle, 1952; Zahn, 1984:278

25. Koningin Beatrix heeft in 1982 in een rede tot topfiguren uit de Amerikaanse zakenwereld gesteld dlat Nederlanders gelijkheid zoeken waar Amerikanen vrijheid zoeken; zie Salomonson, 1982: 
26. van Kleffens, 1940; Von der Dunk, 1980:143; zie ook de resultaten van recent onderzoek in Stoetzel, 1983:64

27. Baker, 1983; Chorus, 1964:155, 172; Rentes de Carvalho, $1982: 158$

28. Hofstede, 1980:121

29. Chorus, 1964:62. Er zijn aanwijzingen dat de regionale culturen van de Duitse Hanzesteden Hamburg en Bremen en van de Baltische landen Estland, Letland en Litauen overeenkomstige trekken vertonen.

30. Zahn, 1984:152

31. World Development Report, 1984: Table 24.

32. Hofstede, 1980:181, 208. Het belang van deze index is gesignaleerd door de Oostenrijkers Gaspari en Millendorfer (1978). In mijn boek uit 1980 toon ik het verband tussen verplegenden per arts en onzekerheidsvermijding aan voor 15 landen. De nieuwere gegevens uit het World Development Report (1984) maken een vergelijking mogelijk van 44 landen. Over deze 44 landen is de rangcorrelatie (Spearman) tussen de twee grootheden Rho=0,40, significant op het niveau 0,001 .

33. Morris, 1979

34. De correlatie tussen BNP per hoofd en de Morris-index voor 40 landen is $r=0,73, r^{2}=0,53$.

35. Rangcorrelatie Masculiniteits-index met Morris-index voor 19 landen: Rho $=-0,51$, significant op het niveau 0,05 . De correlatie wordt gedrukt door de uitzonderingspositie van Japan, dat. ais extreem masculien land toch hoog op de Morris-index scoort.

36. Van der Woude, 1985:58.

37. Parker, 1977:21 38. Rozendaal, 1986 39. Vinocur, 1971; Stoetzell, 1983:265 ff.

40. de Baena, 1966:74

41. Durkheim 1930

42. Lynn, 1971; Lynn \& Hampson, 1975. De rangcorrelatie tussen neuroticisme en onzekerheidsvermijding over 18 landen is Rho $=0,73$.

43. Chorus, 1964:124

44. op. cit $: 109$

45. Aberbach \& Putnam, 1977. Over de vijf landen die zij onderzochten, correleert het percentage juristen bij de hogere overheid significant met de IBM-onzekerheidswermijdings-index: Rho $=0,90$.

46. Hofstede, 1980:180, 207

47. Van Doorn (1986) wijt het stijgende aantal "affaires" en de stijgende kleine criminaliteit an de toenemende complexiteit 
in het maatschappelijk en politiek gebeuren; de onmacht van de overheid om een snelheidslimiet vast te stellen en die ook te handhaven kan ook op deze manier worden werklaard.

48. Polak, 1986; Hofstede, 1980:180

49. Bond, 1987. De correlatie tussern economische groei (in wan BNP per inwoner) en Confucialans Dynamisme over 22 landen is $r=0.73$ 


\section{Lilerafuer}

Abrams, M. "Mass views of the future: a report from the Netherlands". Futures, $197 \%, 103-115$.

Aberbach, J.D. \& Putnam, R.D. Path to the top: the origins and careers of political and adninistrative elites". Bijdrage an conferentie: Frontiers in Comparative Analyses of Bureaucratic and Political Elites. Wassenaar, november 1977 .

Amicis, E. de. Nederland en zïn bewoners. Utrecht: Veen, 1985 (1876).

Baena, Duke de. The Dutch Puzzle. Den Haag: Boucher, 1966.

Baker, V. 'Wat de Amerikanen van òns vinden'. Intermediair, 1983, 19. $29-30$.

Barzini, L. The Europeans. New York: Simon \& Schuster 1983.

Bond, M. 'Chinese values and the search for culure-free dimensions of culture: the Chinese culture connection'. Journal of CrossCuliural Psychology, 1987, ter perse.

Chors, A. De Nederlander, uiterlijk en innerlijk: een karakteristiek. Leiden: Sijthoff, 1964.

Doom, J.A.A. wan. "Is Nederland Nederland nog wel? De machteloosheid wan het fatsoen". NRC.Handelsblad, 1986, 15 now.

Dunk, H.W. von der. 'Die Niederlande und Deutschland: Randvermerke zu einer Nachbarschaft" . In: Die Niederlände: Korrespondenten berichten. Zurich: Hecht, 1980, 131-149.

Durkhein, E. Le suicide: érude de sociologie. Paris: Presses Universitaires de France, 1930 (1897).

Elsevier's Magazine. 'Merk toch hoe sterk: succes in Holland'. Geheel nummer, $1987,43,1$.

Gaspari, C. \& Millendorfer, J. Konturen einder Wende: Strategien fü die Zukunft. Graz: Styria, 1978.

Gortzak, H. Hoop zonder illusies: memoires van een communist. Amsterdam: Bert Bakker, 1985.

Goudsblom, Y. Dutch Society. New York: Random House, 1967.

Hofstede, G. Culture's Consequences: International Differences in Wark-Related Values. Beverly Hills, Califonie: Sage, 1980.

Hofstede, G. 'Dimensions of national culture in fifty countries and three regions". In: J.B. Deregowsk:, S Dziurawiec \& R.C. Annis (red.), Expiscations in Cross-Cultural Psychology. Lisse, Swets \& Zeitlinger, 1983, 335-355. 
Hofstede, $G$. "American and Dutch businesis values: similarities and differences". In: P. Sanders \& J.N. Yanowzas (red.), Managing in a Global Economy. Tilburg, KUB, 1985.

Huizinga, J. Nederlands geestesmerk. Leiden: Sijthoff, 1946.

Inglehart, R. \& Rabier, I.R. Trust Between Nations: Primordial Ties, Social Learning, and Economic Development. Ongepubliceer de woordruk, 1983.

Kleffens, E.N. wan. The Rape of the Netherlands. Landon: Hodder \& Stoughton, 1940.

Kousbroek, R. 'Het Rhemrev-rapport'. NRC-Handelsblad. 1987, 27 feb. Lynn, R. Persomality and National Character. Oxford: Pergamon. 1971.

Lynn, R. \& Hampson, S.L. National differences in Extraversion and neuroticism'. British Jounal of Social and Clinical Psychology, $1975,14,3,223-240$.

Meertens, P.J. 'Ce qu'on a dit des Pays-Bas'. Revue de Psychologie des Peuples, $1950,1,11-32$.

Morris, M.D. Measuring the Condition of the World's Poor: the Physical Quality of Life Index. New York: Pergamon, 1979.

Parker, O. The Dutch Revolt, $2 \mathrm{e}$ druk. Harmondsworth, Middlesex: Penguin. 1985.

Phillips, D. De naakte Nederlander: kritische overpeinzingen. Amsterdam: Bert Bakker, 1985.

Polak, I. "Legitimatieplicht -een kwestie van onzekerheid". Trouw, 1986, 16 aug.

Pottle, F.A. (red.) Boswell in Holland 1763-1764. London: Heinemann, 1952.

Rentes de Carvalho, J. Waar die andere God woont. 3e druk. Amsterdam: Synopsis, 1982.

Rozendaal, S. 'Nederlanders: de langsten ter wereld'. Elsevier's Magazime, $1986,42,48,56-64$.

Salomonson, A. 'Banket met beroemdheden besluit koninklijk bezoek aan Los Angeles'. NRC-Handelsblad, 1982, 22 juni.

Stoetzel, J. Les Valeurs du temps présent: wne enquête Européenne. Paris: Presses Universitaires de France, 1983.

Vinoeur, J. 'Happy Holland keeps its cool' "International Herald Tri. bune" 1971, 20 sept.

Voorhoeve, J.J.C. Peace, Profits and Principles: A Study of Dutch Foreign Policy: Den Hagg: Martinus Nijhoff, 1979.

World Development Report 1984. Washington D.C.: Intemational Bank for Reconstruction and Development, 1984.

Woude, A.M. wan der. 'Bewolking en gezin in Nederland'. In F.L. wan Holthoon (red.) De Nederlandse samenleving sinds 1815: wording en samenhang, Assen: wan Gorcum, 1985, 19-70. 
Zahn, E. Das unbekannte Holland: Regenten, Rebellen und Reformatoren. Berlin: Siedler, 1984. 